\title{
Presidential Position-Taking, Presidential Success, and Interest Group Activity
}

Keywords: lobbying, president, policymaking, interest groups, agenda-setting, Congress

\author{
Amy Melissa McKay \\ Brian Webb \\ Congress and the Presidency 46(1): 89-108 \\ Accepted 1 Sep 2018, Published online 12 Dec 2018
}

\begin{abstract}
Do lobby groups help the U.S. president achieve policy objectives? Existing research seldom evaluates interest groups and the president in conjunction, and as a result we have little systematic knowledge about how groups respond to presidential actions or whether they assist in realizing the president's policy agenda. Building on existing data obtained through interviews with 776 lobbyists conducted in 1983-84, combined with variables we generate describing issue salience, congressional attention, the political context, and policy adoption, we show that interest groups adjusted their lobbying activity to better reflect the president's voiced preferences about the federal agenda. Despite this strategy, we find that lobby groups had no significant marginal effect on policy adoption when controlling for the overwhelming influence of the president.
\end{abstract}


When the president reveals his or her policy agenda to Congress, interest group lobbyists pay attention. In one sentence the president can instantly put a policy proposal on the top of the federal agenda and make it more likely to become law. Presidential attention to a legislative or bureaucratic proposal signals to interested advocacy groups that the proposal will receive meaningful consideration in Congress or in federal agencies. These cues encourage interested groups to lobby on this issue now and leave other issues they care about for later. Yet few scholars have evaluated how interest groups respond to policy proposals on which the president takes a position. Moreover, it remains unclear whether following presidential agenda cues is even an effective strategy, since interest groups' relative importance in shaping federal policymaking remains unclear.

The dearth of literature combining the president with lobbyists is forgivable. Few scholars have the resources to mount the large-scale studies necessary to systematically assess the lobbying activity surrounding policy proposals and the effect of this lobbying on policy outcomes. An important exception is Baumgartner, Berry, Hojnacki, Kimball, and Leech (2009), who studied the ability of interest group lobbyists to achieve policy goals, though they did not directly evaluate how presidents may condition lobby groups' success. In a similar project, Heinz, Laumann, Salisbury, and Nelson (1990) interviewed hundreds of lobbyists and government officials. Their focus was on the careers of and networks among these actors; they did not seek to explain policy outcomes. Meanwhile, a wholly distinct set of scholars has studied the ability of presidents to secure legislation and to influence regulatory outputs, and these presidential studies pay little attention to the role of interest groups in policymaking (e.g., Bond and Fleisher 2000; Cameron 2000, Krehbiel 1998, Beckmann 2010). 
In this research we revisit the data produced by the Heinz et al. (1990) team and, importantly, add new variables capturing whether or not the president took a position on the issue, the salience of the measure, congressional attention to the issue, and whether or not the proposal became law. Consistent with previous research, the data suggest that presidential position-taking on an issue did significantly increase the incidence and volume of lobbying efforts on the issue, even while controlling for a number of other important factors. This lobbying did not, however, seem to help the president achieve his or her stated preference, as the president's influence seems to dominate over the lobbying efforts of interest groups.

Our article makes two key contributions to the field. First, we identify a heretofore neglected strategy on the part of lobby groups regarding how groups utilize presidential positiontaking to maintain their organizations and help build coalitions. Second, we draw a link between the literatures regarding interest group lobbying and presidential effectiveness by arguing that presidential support is even more important than lobbying in explaining whether proposed federal laws were adopted. Relying on data collected in interviews with the largest sample of lobbyists ever assembled, we advance understanding of the influence of both the president and interest groups on policymaking in Washington.

\section{Previous Research}

Studies of the influence of presidents and of lobby groups over policy adoption are numerous. But their conclusions are not always mutually consistent, and very few have looked at the two actors in a single model. Regarding the influence of the president, an impressive literature examines the extent of influence the president has in both setting the federal agenda and in securing his or her preferred policy outcomes. Scholars broadly agree that the president has considerable influence over the content of the federal agenda (Neustadt 1990, Kingdon 1995, 
Edwards and Wood 1999, Baumgartner and Jones 2009, Edwards and Barrett 2000, Rutledge and Larsen-Price 2014). Light (1999) and Lovett, Bevan and Baumgartner (2015), further, show that the president's agenda-setting power is greater when the president's popularity is higher. Most scholars also concur that the president has a strong effect on the outcome of proposed policies. Studies show that legislation that is lobbied on by the White House is significantly more likely to pass than is legislation that is not lobbied on by the president (Beckmann 2010, Edwards and Barrett 2000, Baumgartner et al. 2009'). The literature is not unified on this point, however, as some studies have found that presidential support alone does little to help a proposal's chances of becoming law (Edwards 1989, Bond and Fleisher 2000, Collier and Sullivan 1995, Neustadt 1990, Wood and Lee 2009).

The literature on the influence of interest groups is similarly voluminous, though Baumgartner and Leech (1998) demonstrated that the literature was an unsystematic collection of case studies that do not build on one another. We know that organized interest groups have some ability to influence the policy process (Kingdon 1989; Baumgartner et al. 2009). Some find an indirect relationship whereby groups reward or punish members of Congress for their voting behavior (Grenzke 1989), buy access to members of Congress (Langbein 1986, Kalla and Broockman 2016), or encourage Members and their staffers to spend time and energy on issues important to interest groups (Hall and Wayman 1990). Compared to the president, though, interest groups are at a disadvantage when it comes to achieving policy outcomes. The president can almost always influence the congressional agenda and is usually successful in shaping legislation, while lobby groups' influence is often difficult to detect at all.

The small literature that addresses the relationship between interest groups and the president has presented some evidence that groups respond to presidential efforts to set the 
agenda, but the relationship is nuanced. Extending earlier work that showed that interest groups respond to the congressional agenda (Leech, Baumgartner, La Pira and Semanko 2005), Baumgartner, Price, Leech and Rutledge (2011) added to the Leech et al. (2005) dataset a measure of presidential attention. Baumgartner et al. (2011) showed that the effects of presidential agenda-setting on lobbying levels in the years 1996-2004 depended on the issue area: In issue areas in which the authors assert the president is dominant (such as health care and labor), Baumgartner et al. (2011) found that increased presidential attention tended to redirect lobbyists to focus their efforts on executive agencies rather than on Congress. Meanwhile, in policy domains that are not dominated by the president (such as energy and agriculture), Baumgartner et al. (2011) found that presidential attention to an issue had no significant effect on legislative lobbying when also controlling for congressional hearings and congressionally determined federal expenditures on those issues. Our study builds on theirs by assessing the effects of presidential agenda-setting on interest groups at a previous point in time using wholly separate data.

\section{Theory and Hypotheses}

The foregoing discussion leads us to two key expectations. Our first theoretical argument is that presidential position-taking tends to intensify groups' congressional lobbying on presidential agenda items. Doing so has at least two benefits, both driven by seminal arguments in the literature.

First, lobbying on presidential agenda item assists interest groups in maintaining their organizations. It is well established that interest group leaders solve the collective action problem by providing selective benefits to their members (Clark and Wilson 1961, Olson 1965, Salisbury 1969, Walker 1991, Kollman 1998). Lowery and Gray's (1996) claim goes further still, asserting 
that organized interests' primary objective is simply to stay alive. Among the selective benefits groups offer their supporters are expressive benefits that allow individuals to vocally articulate their concerns and values and solidary benefits that draw members together in a shared commitment and fate (Salisbury 1969). By lobbying on an issue to which the president has drawn attention, a group can garner publicity for the group's efforts. This publicity amplifies the expressive and solidary benefits that attract supporters and generate contributions to the group. Groups may, for example, use presidential positions as a rallying cry in mailers that always include an envelope for contributions. Business firms and trade associations also commonly sponsor political action committees that rely on voluntary donations. Both business and nonbusiness interests depend on this social and financial capital to survive as organizations.

The second rationale for greater lobbying on presidential agenda items - and one that is compatible with the first rationale - is that groups use presidential position-taking to spur coalition-building with other interested groups. Working in alliances is a common behavior of interest groups (Hojnacki 1997, Hula 1999, Mahoney 2007, Heaney and Leifeld 2018): a survey of Washington lobbyists found that 96 percent had had one or more coalition partners in the previous 12 months, and more than half spent a day or more per week on coalition-building activities (Talbot 2009). Since a few issues attract the vast majority of lobbying activity (Baumgartner and Leech 2001), working on one of these issues maximizes the number of other interest organizations active on the same issue with whom a group can form a coalition. The heterogeneity of interest group types on each side of Baumgartner et al.'s (2009) 98 issues is further evidence of Washington lobby groups' desire and ability to form coalitions with other groups on the same side of an issue. 
We take no position on which rationale—organizational maintenance or coalitionbuilding — better explains increased lobbying on presidential agenda items, because the literature contains compelling evidence for both explanations, and the two may even work together. As just one example, Baumgartner et al. (2009, Chapter 6) note that coalitions can create greater publicity than individual lobby groups can generate; thus coalitions can serve to maintain a group's support from members and donors.

Importantly,[WB1] neither of these rationales for intensifying lobbying on presidential agenda items is linked to groups' probability of winning on the issue. We contend that intensified lobbying that follows presidential position-taking occurs on both sides of the proposal. If it were the case that when the president pressed support for a measure, lobbyists in favor lobbied more vigorously while lobbyists opposed lobbied less vigorously, this would suggest that the presidential position-taking served as a cue as to which side would win, and that lobbyists in favor responded by associating themselves with the winning position. Conversely, if, when the president took a position against a proposal, groups that opposed it lobbied more intensely and lobbyists in support lobbied less intensely, this would suggest that groups are conserving resources by intensifying their lobbying efforts on just those issues on which they think they will win. But if presidential position-taking intensifies lobbying by both supporters and opponents of the proposal, it suggests that the groups are taking advantage of the salience and prominence of the issue — which is what we expect—rather than trying to maximize their record of wins on policy outcomes.

In short, our lobbying intensity hypothesis holds that interest groups that share an interest in an agenda item on which the president takes a position (regardless of whether they support or 
oppose the president's position) will intensify their efforts on these presidential agenda items, saving other issues for later. ${ }^{2}$

If it is correct that lobby groups are more motivated by their fight to survive than by achieving specific policy outcomes,

Our second theoretical argument is that the president has an influence over the likelihood that a policy is adopted. We expect that voiced presidential support for a measure increases the probability of adoption, and likewise, voiced presidential opposition reduces the chances of adoption. This much is consistent with the majority of literature on presidential legislative success (Beckmann 2010, Edwards and Barrett 2000, Baumgartner et al. 2009). Our point of departure is to invoke the lobbying efforts of interest groups. Our presidential dominance hypothesis suggests that the relationship between the president's voiced position on an issue and whether the proposal is ultimately adopted is at least as strong, and possibly stronger than, the association between interest group lobbying activity and adoption of a proposal. The logic While other scholars have examined the relative power of the president to influence the content of the policy agenda (Baumgartner and Jones 2009), or the relative ability of the president and fellow high-level government officials to influence policy outcomes (Baumgartner et al. 2009), we know of no other study that squarely addresses the capacity of the president to influence federal policy adoption relative to the same capacity on the part of interest group lobbyists.

\section{Thus, if our two theoretical expectations hold, groups take heed of public presidential} $\underline{\text { statements in order to appeal to potential coalition partners and current and prospective members }}$ or donors. If this is correct, then we should observe, first, that the president has significant 
influence over policy adoption and, second, if lobby groups on both sides respond equally to presidential position-taking.|[WB2]

Bringing these two theoretical expectations together: If the president has significant influence over policy adoption, and if lobby groups on both sides respond equally to presidential position-taking, it is further evidence that the group's goals are less about securing particular policy outcomes and more about appealing to potential coalition partners and current and prospective members and donors.

\section{Data and Methods}

The data for this project were originally derived from face-to-face interviews conducted by Heinz, Laumann, Nelson, and Salisbury (1990) with 776 Washington lobbyists. No other study of lobbying has interviewed, or even surveyed, so many lobbyists. This dataset contains details about the background, ideology, viewpoint, actions, and assessments of an uncommonly large set of actors trying to influence government. Lobbyists were selected through elite interviews with clients, lobbyists, and government officials, in order to capture the most salient issues and the most prominent lobbyists. The resulting sample is representative of all Washington lobbying, with the most active lobbyists being the most likely to be sampled, but including a few representatives from smaller, less well-known organizations. ${ }^{3}$

The authors developed a list of 22 policy proposals in four issue domains - agriculture, energy, health, and labor. These issues were culled from a review of the Congressional Quarterly and the New York Times covering the years of 1977-1982, with greater emphasis on the latter years (70 percent are proposed in or after 1980). Eleven issues related to multiple policy areas, reducing the total number of unique proposals to 77-a number unmatched except 
by Baumgartner et al. (2009), who interviewed some 300 respondents regarding 98 separate issues.

Each lobbyist was asked to identify up to five issues that he or she worked on from the list of 22. On each of these, the lobbyists were queried about their position on the issue, the lobbying tactics they used, the conflict surrounding the proposal, and how many of their objectives they achieved. About a fifth of the proposals were initiated in federal agencies, allowing us to test our hypotheses in both the legislative and the executive branches of government. While some scholars have noted changes in the lobbying population between the 1980s and today (see Berry and Wilcox 2009 for a review), these changes have all been in the direction of the greater proliferation, diversity, and influence of lobbyists. Both the "advocacy explosion" (Nownes and Neeley 1996) and the steep increase in business lobbying (Drutman 2015) were well under way by the 1980s. As such we believe the older data are less likely to identify a relationship between lobbying, the presidential agenda, and policy adoptions than newer data would be. We make no claims about the effects of more recent presidents on lobbyists' activities or how the two may interact to influence policy outcomes; however, it is worth noting that Baumgartner et al's (2009) intensive project on the effects of lobbying in the policy process are consistent with ours regarding the considerable importance of lobbyists' highlevel government allies.

\section{Dependent Variables}

Lobbying intensity. The lobbying intensity hypothesis holds that when the president voices a position on a policy proposal, more lobbyists will lobby on the issue, and in addition, each lobbyist is more likely to lobby. Our data allow us to test both propositions, which we do using separate levels of analysis. The first dependent variable, lobbying intensity, is measured as the number of lobbyists actively working on the issue (i.e., it was one of up to five issues they 
said they worked on in the original interviews.). Counting lobbyists as a way to measure the size of a lobbying coalition is consistent with previous studies (e.g., Austen-Smith \& Wright 1994; Baumgartner \& Leech 2001; Heberlig 2005; Apollonio 2005; Wright, 1990), and the results hold when substituting the number of employers for the number of lobbyists. The unit of analysis is the 77 policy proposals. We model this relationship using negative binomial regression, which is the appropriate functional form for count data in which the variance exceeds the mean.

Decision to lobby. To test whether a given lobbyist is more likely to lobby on an issue on which the president has taken a position, we expand the unit of analysis from 77 policy proposals to the 3,177 lobbyist-proposals, where each observation is a particular lobbyist interested in a particular issue. (Errors are clustered on the issue since some variables will be consistent across issues.) The dependent variable used in this alternative analysis, decision to lobby, is an indicator of whether or not each lobbyist contacted Congress on each issue. As the variable is dichotomous, we estimate it using logistical regression.

Policy adoption. To test the presidential success hypothesis, we develop a variable that is absent from the original Heinz et al. (1990) data: whether the policy proposal was adopted or not. We construct the policy adoption dependent variable by comparing the proposal, as described to interviewees, with the legislative database Congress.gov, the annual Congressional Quarterly Almanac, the Federal Register, and in some cases newspaper articles archived by Lexis-Nexis. The statements given to respondents present a certain version of the proposal, eliminating other forms it may have taken during the legislative or rulemaking process; this makes it straightforward to code whether or not the proposal was adopted in Congress or a federal agency. The unit of analysis for this hypothesis is the 77 policy proposals. We predict policy adoption using logistic regression. 


\section{Key Independent Variables}

Presidential Position-Taking and Presidential Position. The Heinz et al. (1990) data did not include a measure of the president's position on each issue or even whether the president voiced a position. To assess the effect of presidential support for or opposition to a measure, we compile information from Congressional Quarterly’s annual summary of Presidential Position Votes, which identifies congressional decisions on which the president took a clear stand. For legislative and agency-initiated policy proposals that were not the subject of a vote in Congress, we use Congressional Quarterly Almanac summaries and Lexis-Nexis-archived news articles to determine whether the president is mentioned as taking a clear position on the proposal. To predict lobbying intensity, we code presidential position-taking as 1 if the president voices voiced any position on the issue and 0 otherwise. To judge the president's influence over policy adoption, the key explanatory variable is the president's position, where the president's voiced support is coded 1, the president's voiced opposition is coded -1, and no voiced position is coded 0. The former method allows us to measure the effect of the president on lobbying activity generally, while the latter method helps us assess whether the president can successfully pull policy outcomes in his or her preferred direction.

Lobbying Pressure. To compare the relative influence of the president and interest groups, we use a measure of the number of lobbyists in favor of the proposal and the number of lobbyists against. This choice addresses two modeling specification challenges. First, the model implicitly includes an interaction between the president's position and those lobbyists working on the same side of the proposal. Second, the model explicitly controls for the possibility that lobbying on one side of the issue is counteracted by lobbying on the other side, which could lead to a misguided conclusion that lobbying has no effect on the outcome (Baumgartner et al. 2009). 
Lobbyists were asked whether their position was for or against the proposal (or whether they took some other stance). The description of each policy proposal makes clear what a positive or negative preference would be. ${ }^{4}$ We summed these for each side of each issue to generate number of lobbyists in support and number of lobbyists in opposition. Finally, in addition to including positive lobbying and negative lobbying in the same model, since these are naturally somewhat correlated $(\mathrm{rho}=0.48)$, we separate them in two additional models.

\section{Control Variables}

Salience. We readily acknowledge that factors other than presidential position-taking may increase lobbying activity and affect policy outcomes. In particular, the salience or general interest in an issue before the relevant policymaking activity commenced is likely to be associated with both greater lobbying intensity and greater likelihood that the president takes a position on the issue. To create an exogenous measure of issue salience, we look back ten years before the policy is proposed. This mitigates against the potential for simultaneous causation of issue salience with regard to either presidential position-taking or lobbying activity. Our measure

of salience is the sum of the number of times the issue was mentioned in the New York Times and the Washington Post in the ten years before the proposal was considered for adoption. Our search used key words describing each proposal which were supplied by the original authors. Due to the importance of controlling for issue salience, and to simplify interpretation, we estimate an additional model in which this salience measure is divided into tertiles from which we create indicator variables for high and for low salience.

Conflict. Similar to, but not the same as, the salience of an issue is the level of conflict surrounding a proposal. We suspect that conflict is positively related to lobbying activity, while, consistent with the literature, we expect conflict to be negatively related to the probability that 
the proposal is adopted. To gauge conflict, we use the lobbyists' assessment of the conflict on each issue they worked on from "none" to "intense" on a five-point scale. For the models in which the unit of analysis is the policy proposal, we use the mean level of conflict reported by all lobbyists working on the issue. Conflict and salience are not highly correlated $(\rho=.23)$. In the models in which salience is divided into tertiles, we also divide conflict into tertiles. (High conflict and high salience are correlated at $\rho=.20)$.

Congressional attention. Recent research, taking advantage of the U.S. Policy Agendas Project (PAP), has found that congressional attention to an issue area has an effect on the number of individuals who register to lobby in that issue area (Baumgartner et al. 2011, Leech et al. 2005). Like Baumgartner et al. (2011), we include in our models the number of congressional hearings in our four policy domains (what PAP labels the "major topic") over the previous 6 months. We expect that the president has an effect on the level of lobbying activity that is above and beyond the effect of general congressional attention in the issue area.

Capacity to lobby. Another variable that may contribute to the number of actions a lobbyist takes on a specific issue can be described as the capacity to lobby. We measure this as the amount of money the lobbyist's employer brings in in a given year, i.e., its annual budget or revenue. The age of the data mean that we must impute this number in some cases, which we do by regression based on the number of staff at the organization and whether or not the group represents business. This number varies by lobby group, so it is included only in the models in which the lobbyist-issue is the unit of analysis.

Divided government. The decision of a president to "go public" (Kernell 1997; CanesWrone 2006; Tedin, Rottinghaus and Rodgers 2011; Davis 2014), as well as the ability of a president to achieve his or her desired outcome, must depend in part on the current political 
situation. More specifically, presidential power is likely to vary depending on whether the president's party is the majority party of the House and of the Senate. Greater ideological division between the parties in a legislature has been shown to increase the probability of gridlock, meaning fewer policies are adopted (Bowling and Ferguson 2001, Rogers 2005). Mayhew (1991), however, found that divided government did not reduce legislative productivity (but see Kelly 1993). We considered several ways of measuring the partisan nature of Congress and found them to be highly correlated. ${ }^{5}$ For ease of presentation, we use a dichotomous measure of whether government is divided or not. From 1981-1982 inter-chamber division coincides with inter-branch division, comprising 48 percent of the proposals.

Agency proposals. Finally, whether a proposal was initiated by a federal agency or by Congress should have an effect on both the president's choice to voice a position on the matter and the chances that the proposal succeeds. We therefore code all 77 policy proposals as agencyinitiated or Congress-initiated, according to the way the proposal was worded in information initially provided to respondents. For example, "EPA adopts tougher sulfur emission standards for new coal-fired power plants" is coded 1 for agency-initiated, while "Congress considers a $\$ 500$ to $\$ 700$ million cut in Medicare by repealing periodic interim payments" is coded 0 . Descriptive statistics appear in Table 1 and our theoretical expectations appear in Table 2.

\section{Analysis}

\section{Predicting Lobbying Intensity}

Presidential position-taking is a significant predictor of greater lobbying activity on a proposal, even when controlling for salience, conflict, and other relevant factors. The models in Table 3 show that when the president took a position on a proposal in these data, both the number of active lobbyists, and the probability that each lobbyist in the dataset lobbied Congress 
about the issue, were significantly greater. When the president voiced support for or opposition to a proposed policy, and controlling for salience, conflict, divided government, congressional attention, and which branch initiated the proposal, the first model predicts that an additional 20 more individual lobbyists, or 57 percent more, worked on the issue than when the president was silent on the matter. The second model, under conditions of high salience, high conflict, divided government, and legislative rather than agency administrative proposals of the measure, predicts that the decision of the president to take a position on the issue increases the number of lobbyists working on it by 24 individuals, or 40 percent.

The third model in Table 3 shows that presidential position-taking on an issue is associated with a greater likelihood that each lobbyist contacts Congress about the issue. This model suggests that the probability that a given lobbyist contacted Congress on an issue increased by about 13 percent when the president voiced a position on the issue relative to when no position was taken. And in the fourth model, the predicted probability that a lobbyist contacts Congress on an issue moves from 0.62 to 0.68 when the president voices a position. In short, presidential position-taking was consistently and significantly associated with greater lobbying activity during our time period.

Highly salient issues are associated with both greater lobbying volume and a greater probability of lobbying Congress, though the raw count salience measure is not significant in predicting either dependent variable. But the significance of presidential position-taking persists in spite of controlling for salience. It is not even clear that the salience of an issue contributes to the president's decision to take a position on an issue. A bivariate logistical regression of salience (or high salience) on the president's decision whether to voice a position on a proposal finds no significant relationship for either high salience $(0.411$ at $\mathrm{p}=.489)$ nor the salience count 
variable $(0.022$ at $p=.118) .{ }^{6}$ This null effect provides evidence that issue salience is not simultaneously driving lobbying activity and presidential position-taking.

Conflict is not a significant predictor of the volume of lobbying activity, while conflict is a significant predictor of a given lobbyist's decision to contact Congress on an issue. A lobbyist's perception of the conflict surrounding an issue is also a significant predictor of the lobbyist's decision to contact an agency and the decision to appeal to public opinion on the matter (not shown). Thus salience is associated with the number of parties motivated to lobby, while conflict may be an indicator that lobbyists anticipate greater difficulty in winning their preferred policy and therefore are more likely to lobby and to lobby in more ways.

Congressional attention, as measured by the number of hearings in the particular policy domain (agriculture, energy, health, or labor) over the previous six months, is not a significant predictor in these data of either the volume of lobbying or the decision to lobby Congress on the matter. Lobbying capacity, as estimated as the annual revenue of the lobbyist's employer, is predictably associated with the volume and incidence of lobbying on the issue. Divided government predicts a higher volume of lobbying in the first model, but divided government is not a significant predictor of lobbying activity when high-salience issues are accounted for, nor is it a significant predictor of a lobbyist's decision to contact Congress. Agency-initiated proposals did not generate a significantly greater or lesser volume of lobbying generally, but such proposals are associated with a significantly reduced probability of lobbying Congress when accounting for high-salience and high-conflict issues (seen in the fourth model of Table 3).

The relationships between presidential position-taking and the dependent variables in this table are all statistically significant at $\mathrm{p}<0.05$ and are robust to alternative modeling specifications, including, for the proposal-level models, ordinary least-squares regression and 
tobit, and for the individual-level model, clustering errors by the lobbyist or the lobbyist's employer. $^{7}$

\section{Predicting Presidential Success}

Presidential support for or opposition to a measure $(-1,0$, or 1$)$ had a large and significant effect on whether the proposals in the data were adopted - in fact, it is the single largest predictor of policy adoption in the models. The probability that the proposal is adopted as predicted by the first (main) model in Table 4 moves from 0.18 to .81 as the president's voiced position is adjusted from against a measure to in support of a measure (i.e., -1 to 1). When a president openly supports a measure, the predicted probability of policy adoption increases by 62 percent, moving from 0.50 to 0.81 . When the president objects to a proposal, the predicted probability of policy adoption decreases by 64 percent, moving from 0.50 to 0.18 .

The association between presidential position-taking and policy adoption is notably stronger than the relationship between lobbying and policy adoption. Table 4 includes, in separate models, the number of lobbyists who favored the proposed policy, the number of lobbyists opposed, and both values. In all three cases, while the coefficient has the expected sign, the numbers of lobbyists working for or against the proposal do not have a significant effect on the probability that the proposal is adopted at $\mathrm{p}<.05$.

Regarding the control variables in Table 4, salience and agency proposals are positively but not significantly associated with the predicted outcome, and conflict, congressional attention, and divided government are negatively but not significantly associated with the probable outcome. Maximum-likelihood $\mathrm{R}^{2}$ statistics indicate that the models explain up to 23 percent of the variance, and the probability $>\chi^{2}$ statistic shows that the models are significant at $\mathrm{p}<.05$. 


\section{Alternative Predictors of Presidential Success}

The literature suggests alternative variables that contribute to presidential success. In complementary analyses, we evaluate these with our data, controlling in all cases for issue salience, the conflict surrounding the issue, the presence or absence of divided government, and whether or not the proposal was initiated by a federal agency. Our data support previous research that has found that the effect of presidential support on legislative outcomes is conditional on the public's approval of the president (Light 1999; Lovett, Bevan and Baumgartner 2014). Both the position of the president, and an interaction term representing the president's position multiplied by the president's approval rating in the month in which the proposal was made, significantly affect the policy outcome.

However, several arguments and variables used by other researchers do not find strong support in our data. The success of the president on these 77 proposals was not significantly related to the number of positions the president took in the same year (Rivers and Rose 1985), the number of fellow partisans in Congress (Krehbiel 1998, Howell et al. 2000), whether the proposal was salient and complex (Canes-Wrone and de Marchi 2002), ${ }^{8}$ whether government was divided or unified (Edwards and Barrett 2000), ${ }^{9}$ whether the or whether the president was in the honeymoon period (Beckmann and Godfrey 2007, Light 1999, Brody 1991, McCarty 1997; but note that our data contain only one honeymoon period). We acknowledge that differences between the data used in the present study and the data used in the aforementioned studies are largely responsible for the differences in our substantive conclusions. Still, the insignificance of these alternative predictors of presidential success offer further evidence that presidential position-taking was a powerful indicator that the president's preferred outcome would be realized. 
In further analyses, we evaluated whether presidential success depended on the presence of unified government; it did not.

We also tested — an effect second in explanatory power only to this same variable when interacted with the president's approval rating. [WB3][WB4]

\section{Conclusions}

Previous research is not dispositive about the ability of either interest groups or of the U.S. president to influence federal policy outcomes. An overlooked explanation for the varied findings is the relationship between interest group lobbying and presidential position-taking. As in previous studies using different data (Leech et al. 2005, Baumgartner et al. 2011), we show here that the lobbyists in our data did respond to the president's agenda items. Consistent with our lobbying intensity hypothesis, our analysis finds that when the president took a position on a proposal, lobbying on that proposal—-both for and against the president's position-was greater in volume, and additionally, a given lobbyist was more likely to lobby Congress on the issue. We argue that taking agenda cues from the president allowed groups to enhance their public profile which in turn helped them attract and retain supporters. AS an equally plausible explanation, we argue that groups that focused their lobbying activities on presidential agenda items found it easier than they otherwise would to build coalitions with like-minded groups.

Importantly, though, we stop short of arguing that groups that lobbied on presidential agenda items were more likely than other groups to successfully influence policy adoption. Our presidential dominance hypothesis holds that the president is as successful as lobby groups in influencing policy adoption, if not more so. The analysis presented in Table 4 affirms that lobbying pressure had no independent relationship with the probability that the proposal was 
adopted when compared to the strong association between the president's preference and policy adoption.

Our study suggests that, at least during the five-year period covered by our data, interest groups may have been the third wheel in the relationship between the president and Congress. Interest groups did seem to respond to presidential cues when deciding how to direct their lobbying efforts, but Congress appears to have been significantly more attentive to the preferences of the president than to those of lobby groups. Consequently, presidents seemingly had little to gain from working in concert with lobby groups, and neither the literature nor journalistic accounts have produced much evidence that the two worked together.

We acknowledge that the data used here are now more than 30 years old. Yet the highquality of the data, and the compatibility of the findings with more recent studies, argue for our usage of the data. With the notable exceptions of Baumgartner et al. (2009) and the INTEREURO study (Beyers, Bonafont, Dur, Eising, Fink-Hafner, Lowery, Mahoney, Maloney and Naurin 2014), no study of lobbying and policymaking has come close to the magnitude of the Heinz et al. (1990) data. In the 1980s, as today, in order to get information about which actors want which policy and how they go about lobbying on it, researchers must get it directly from the lobbyists themselves. Even with the Lobbying Disclosure Act of 1995, lobbyists do not have to report how they selected their lobbying agenda nor whether they lobbied or worked with the White House on an issue. And while lobby groups disclose whether they were in contact with high-level officials from the executive branch, they need not indicate who they lobbied, how or how vigorously they lobbied, or whether the group received its preferred result. As such, interview data are required to best explain who gets what, why, and how in U.S. federal policymaking. 


\section{References}

Apollonio, D. E. 2005. "Predictors of Interest Group Lobbying Decisions.” The Forum. 3(3).

Austen-Smith, David, and John R. Wright. 1994. "Counteractive Lobbying." American Journal of Political Science. 38,1: 25-44

Baumgartner, Frank and Beth L. Leech. 1998. Basic Interests: The Importance of Groups in Politics and in Political Science. Princeton: Princeton University Press.

Baumgartner, Frank. R. and Leech, Beth. L. 2001. "Interest Niches and Policy Bandwagons: Patterns of Interest Group Involvement in National Politics.” Journal of Politics, 63: 1191-1213.

Baumgartner, Frank R., and Bryan D. Jones. 2009. Agendas and Instability in American Politics. Chicago: University of Chicago Press.

Baumgartner, Frank R., Jeffrey M. Berry, Marie Hojnacki, David C. Kimball and Beth L. Leech. 2009. Lobbying and Policy Change: Who Wins, Who Loses, and Why. Chicago:

University of Chicago Press.

Baumgartner, Frank R., Heather A. Larsen-Price, Beth L. Leech, and Paul Rutledge. 2011. "Congressional and Presidential Effects on the Demand for Lobbying." Political Research Quarterly. 64: 3.

Beckmann, Matthew N. 2010. Pushing the Agenda: Presidential Leadership in U.S. Lawmaking, 1953-2004. New York: Cambridge University Press.

Beckmann, Matthew N. and Joseph Godfrey. 2007. "The Policy Opportunities in Presidential Honeymoons." Political Research Quarterly 60(2): 250-262.

Berry, Jeffrey M., and Clyde Wilcox. 2009. The Interest Group Society, 5th ed. New York: Pearson/Longman.

Beyers, Jan, Laura Chaques Bonafont, Andreas Dur, Rainer Eising, Danica Fink-Hafner, David Lowery, Christine Mahoney, William Maloney, and Daniel Naurin. 2014. "The InterEuro Project: Logic and Structure." IGA 3: 126-40.

Bond, Jon R., and Richard Fleisher. 2000. "Partisanship and the President's Quest for Votes on the Floor of Congress." In Jon R. Bond and Richard Fleisher (eds.), Polarized Politics: The President and Congress in a Partisan Era. Congressional Quarterly Press.

Bowling, Cynthia J. and Margaret R. Ferguson. 2001. "Divided Government, Interest Representation, and Policy Differences: Competing Explanations of Gridlock in the Fifty States." Journal of Politics 63: 182-206.

Brody, Richard A. 1991. Assessing the President: The Media, Elite Opinion, and Public Support. Stanford: Stanford University Press. 
Cameron, Charles M. 2000. Veto Bargaining: Presidents and the Politics of Negative Power. New York: Cambridge University Press.

Canes-Wrone, Brandice and Scott de Marchi. 2002. "Presidential Approval and Legislative Success." Journal of Politics 64: 491-509.

Canes-Wrone, Brandice. 2006. Who Leads Whom? Presidents, Policy, and the Public. University of Chicago Press.

Clark, Peter B., and James Q. Wilson. 1961. "Incentive Systems: A Theory of Organizations." Administrative Science Quarterly 6,2: 129-66.

Collier, Kenneth and Terry Sullivan. 1995. "New Evidence Undercutting the Linkage of Approval with Presidential Support and Influence.” Journal of Politics 57: 197-209.

Congressional Quarterly. 1977-1982. Congressional Quarterly Almanac. Washington D.C.: Congressional Quarterly Press.

Davis, Julie Hirschfeld. 2014. "Behind Closed Doors, Obama Crafts Executive Actions." The New York Times, 18 August.

Drutman, Lee. 2015. The Business of America is Lobbying: How Corporations Became Politicized and Politics became More Corporate. New York: Oxford University Press.

Edwards, George C. III and Andrew Barrett. 2000. "Presidential Agenda Setting in Congress." In Jon R. Bond and Richard Fleisher (eds.), Polarized Politics: The President and Congress in a Partisan Era. Washington: Congressional Quarterly Press.

Edwards, George C. III. 1989. At the Margins: Presidential Leadership in Congress. New Haven: Yale University Press.

Edwards, George C., and B. Dan Wood. 1999. "Who Influences Whom? The President, Congress, and the Media." The American Political Science Review. 93:2. 327-344.

Grenzke, Janet M. 1989. "Candidate Attributes and PAC Contributions.” Western Political Quarterly, 42(2), 245-264.

Hall, Richard L. and Frank W. Wayman. 1990. "Buying Time: Moneyed Interests and the Mobilization of Bias in Congressional Committees." American Political Science Review 84: 797-82.

Heaney, Michael T., and Philip Leifeld. 2018. "Contributions by Interest Groups to Lobbying Coalitions." The Journal of Politics 80: 494-509.

Heinz, John P., Edward O. Laumann, Robert L. Nelson, and Robert Salisbury. 1990. "Inner Circles or Hollow Cores? Elite Networks in National Policy Systems." Journal of Politics 52: 356-39. 
Heinz, John P., Edward O. Laumann, Robert L. Nelson, and Robert Salisbury. 1993. The Hollow Core: Private Interests in National Policy Making. Cambridge [Mass.]: Harvard University Press.

Hearings. The Policy Agendas Project at the University of Texas at Austin, 2017. www.comparativeagendas.net. Accessed September 26, 2017.

Heberlig, Eric S. 2005. "Getting to Know You and Getting Your Vote: Lobbyists' Uncertainty and the Contacting of Legislators." Political Research Quarterly. 58(3), 511-520.

Howell, William, Scott Adler, Charles Cameron, and Charles Riemann. 2000. "Divided Government and the Legislative Productivity of Congress, 1945-94." Legislative Studies Quarterly 25(2): 285-312.

Hula, Kevin W. 1999. Lobbying Together: Interest Group Coalitions in Legislative Politics: Georgetown University Press.

Kalla, Joshua L. and Broockman, David E. 2016. "Campaign Contributions Facilitate Access to Congressional Officials: A Randomized Field Experiment.” American Journal of Political Science, 60: 545-558.

Kelly, Sean Q. 1993. “Divided We Govern? A Reassessment.” Polity 25: 475-484.

Kernell, Samuel. 1997. Going Public: New Strategies of Presidential Leadership. 3rd ed. Washington: Congressional Quarterly Press

Kingdon, John W. 1989. Congressmen's Voting Decisions. 3rd ed. Ann Arbor: University of Michigan Press.

Kingdon, John W. 1995. Agendas, Alternatives, and Public Policies. New York: Longman.

Kollman, Ken. 1998. Outside Lobbying: Public Opinion and Interest Group Strategies. Princeton, N.J.: Princeton University Press.

Krehbiel, Keith. 1998. Pivotal Politics: A Theory of U.S. Lawmaking. Chicago: University of Chicago Press.

Langbein, Laura I. 1986. "Money and Access: Some Empirical Evidence." Journal of Politics 48(4), 1052-1062.

LaPira, Timothy M. and Thomas, Herschel F. 2017. Revolving Door Lobbying: Public Service, Private Influence, and the Unequal Representation of Interests. Lawrence: University Press of Kansas.

Leech, Beth L., Frank R. Baumgartner, Timothy M. La Pira, and Nicholas A. Semanko. 2005. "Drawing Lobbyists to Washington: Government Activity and the Demand for Advocacy." Political Research Quarterly 58:1. 19-30. 
Light, Paul C. 1999. The President's Agenda: Domestic Policy Choice from Kennedy to Clinton. 3rd ed. Baltimore: Johns Hopkins University Press.

Lovett, John \& Bevan, Shaun \& R. Baumgartner, Frank. 2015. "Popular Presidents Can Affect Congressional Attention, for a Little While.” Policy Studies Journal. 43: 22-43.

Lowery, David and Virginia Gray. 1996. The Population Ecology of Interest Representation: Lobbying Communities in the American States. Ann Arbor, Michigan: University of Michigan Press.

Mahoney, Christine. 2007. "Networking Vs. Allying: The Decision of Interest Groups to Join Coalitions in the Us and the Eu." Journal of European Public Policy 14: 366-83.

Mayhew, David R. 1991. Divided We Govern: Party Control, Lawmaking, and Investigations, 1946-199. New Haven: Yale University Press.

McCarty, Nolan M. 1997. "Reputation and the Veto.” Economics and Politics 9(1): 1-26.

Neustadt, Richard E. 1990. Presidential Power and the Modern Presidents: The Politics of Leadership from Roosevelt to Reagan. New York: Free Press.

Nownes, Anthony J. and Grant W. Neeley. 1996. “Toward an Explanation for Public Interest Group Formation and Proliferation.” Policy Studies Journal. 24: 74-92.

Olson, Mancur. 1965. The Logic of Collective Action: Public Goods and the Theory of Groups. Cambridge [Mass]: Harvard University Press.

Poole, Keith T., and Howard Rosenthal. 2000. Congress: A Political-Economic History of Roll Call Voting. Oxford: Oxford University Press.

Rivers, Douglas and Nancy L. Rose. 1985. "Passing the President's Program: Public Opinion and Presidential Influence in Congress." American Journal of Political Science 29: 183196.

Rogers, James R. 2005. "The Impact of Divided Government on Legislative Production." Public Choice 123: 217-233.

Roper Center. 2008. Presidential Approval Rating Search. Available at http://webapps. ropercenter.uconn.edu/CFIDE/roper/presidential/webroot/presidential_rating_search.cfm.

Rutledge, Paul E. \& A. Larsen Price, Heather. 2014. The President as Agenda Setter-in-Chief: The Dynamics of Congressional and Presidential Agenda Setting. Policy Studies Journal. 42.

Salisbury, Robert H. 1969. “An Exchange Theory of Interest Groups.” Midwest Journal of Political Science, 13: 1-32. 
Salisbury, Robert H., Heinz, John P., Edward O. Laumann, and Robert L. Nelson. 1987. "Who Works with Whom? Interest Group Alliances and Opposition." American Political Science Review 81: 1217-1234.

Talbot, Christy. 2009. "Coalition Building in a New Washington.” Lobbyist.info. https://www.lobbyists.info/2009_coalition_building_survey_results-13-whitepaper

Tedin, Kevin, Brandon Rottinghaus and Harrell Rodgers. 2011. "When the President Goes Public: The Consequences of Communication Mode for Opinion Change Across Issue Types and Groups." Political Research Quarterly. 64. 506-519.

Walker, Jack L. 1991. Mobilizing Interest Groups in America : Patrons, Professions, and Social Movements. Ann Arbor: University of Michigan Press.

Wood, B. Dan and Han Soo Lee. 2009. Explaining the President's Issue-Based Liberalism: Pandering, Partisanship, or Pragmatism. Journal of Politics. 71(4): 1-16.

Wright, John R. 1990 "Contributions, Lobbying, and Committee Voting in the U.S. House of Representatives." The American Political Science Review 84,2: 417-38. 
Table 1. Descriptive Statistics

\begin{tabular}{|c|c|c|c|c|c|c|}
\hline Variable & Data source & Min & Max & Mean & Median & S.D. \\
\hline \multicolumn{7}{|c|}{ Issue as the unit of analysis $(n=77)$} \\
\hline Policy adoption & Authors & 0 & 1 & .532 & 1 & .502 \\
\hline President voiced a position & Authors & 0 & 1 & .325 & 0 & .471 \\
\hline President's position & Authors & -1 & 1 & .117 & 0 & .561 \\
\hline Salience & Authors & 0 & 157 & 10.4 & 2 & 25.6 \\
\hline High salience & Authors & 0 & 1 & .195 & 0 & .399 \\
\hline Average conflict reported & Heinz et al. & 2 & 3.82 & 3.05 & 3.11 & .4 \\
\hline High conflict & Heinz et al. & 0 & 1 & .329 & 0 & .473 \\
\hline $\begin{array}{l}\text { Congressional hearings over } \\
\text { last } 6 \text { months }\end{array}$ & $\begin{array}{l}\text { Policy Agendas } \\
\text { Project }\end{array}$ & 11 & 165 & 49.1 & 42 & 27.6 \\
\hline Divided government & Congress.gov & 0 & 1 & .481 & 0 & .503 \\
\hline Agency-initiated proposal & Authors & 0 & 1 & .182 & 0 & .388 \\
\hline Number of active lobbyists & Heinz et al. & 2 & 263 & 41.7 & 35 & 37.3 \\
\hline Number of lobbyists in favor & Heinz et al. & 0 & 150 & 18.4 & 12 & 20.7 \\
\hline Number of lobbyists opposed & Heinz et al. & 0 & 60 & 14.2 & 11 & 11.9 \\
\hline \multicolumn{7}{|c|}{ Issue-lobbyist as the unit of analysis $(n=3177)$} \\
\hline Decision to lobby & Heinz et al. & 0 & 1 & .642 & 1 & .479 \\
\hline President voiced a position & Authors & 0 & 1 & .423 & 0 & .494 \\
\hline Salience & Authors & 0 & 157 & 13.6 & 4 & 26.2 \\
\hline Conflict & Heinz et al. & 0 & 4 & 3.05 & 3 & .969 \\
\hline $\begin{array}{l}\text { Congressional hearings over } \\
\text { last } 6 \text { months }\end{array}$ & $\begin{array}{l}\text { Policy Agendas } \\
\text { Project }\end{array}$ & 11 & 165 & 45.2 & 38 & 23.6 \\
\hline Divided government & Congress.gov & 0 & 1 & .59 & 1 & .492 \\
\hline Agency-initiated proposal & Authors & 0 & 1 & .173 & 0 & .378 \\
\hline Group's annual revenue $(\ln )$ & Authors & 10.2 & 24.9 & 20.2 & 19.3 & 2.3 \\
\hline
\end{tabular}


Table 2. Theoretical Expectations

\begin{tabular}{lllll}
\multicolumn{1}{c}{ Hypothesis } & \multicolumn{1}{c}{ Dependent variable } & $\begin{array}{l}\text { Key explanatory } \\
\text { variable }\end{array}$ & $\begin{array}{c}\text { Predicted } \\
\text { effect }\end{array}$ & $\begin{array}{l}\text { Unit of } \\
\text { observation }\end{array}$ \\
\hline $\begin{array}{l}\text { Lobbying } \\
\text { intensity }\end{array}$ & $\begin{array}{l}\text { Lobbying intensity: the } \\
\text { number of lobbyists actively } \\
\text { working on the bill }\end{array}$ & $\begin{array}{l}\text { President takes a } \\
\text { position on the } \\
\text { issue }(0 \text { or } 1)\end{array}$ & + & $\begin{array}{l}77 \\
\text { proposals }\end{array}$ \\
\hline $\begin{array}{l}\text { Lobbying } \\
\text { intensity } \\
\text { (robustness } \\
\text { check) }\end{array}$ & $\begin{array}{l}\text { Decision to lobby: whether } \\
\text { the lobbyist contacts } \\
\text { Congress on this issue }\end{array}$ & $\begin{array}{l}\text { President takes a } \\
\text { position on the } \\
\text { issue }(0 \text { or } 1)\end{array}$ & + & $\begin{array}{l}\text { lobbyist- } \\
\text { proposals }\end{array}$ \\
\hline $\begin{array}{l}\text { Presidential } \\
\text { dominance }\end{array}$ & $\begin{array}{l}\text { Policy adoption: whether the } \\
\text { proposal becomes law }\end{array}$ & $\begin{array}{l}\text { President's } \\
\text { position on the } \\
\text { issue }(1,0,-1)\end{array}$ & + & $\begin{array}{l}77 \\
\text { proposals }\end{array}$ \\
\hline
\end{tabular}


Table 3. The influence of presidential support or opposition on lobbying activity

\begin{tabular}{|c|c|c|c|c|}
\hline \multirow[b]{2}{*}{$\begin{array}{l}\text { President voiced a position } \\
\text { on the proposal }\end{array}$} & \multicolumn{2}{|c|}{$\begin{array}{l}\text { Number of active lobbyists } \\
\text { (neg. binomial) }\end{array}$} & \multicolumn{2}{|c|}{$\begin{array}{l}\text { Probability that lobbyist } \\
\text { contacts Congress (logit) }\end{array}$} \\
\hline & $\begin{array}{l}.358 \\
(.162)\end{array}$ & $\begin{array}{l}.341 \\
(.147)\end{array}$ & $\begin{array}{l}.251 \\
(.087)\end{array}$ & $\begin{array}{l}.232 \\
(.082)\end{array}$ \\
\hline Issue salience & $\begin{array}{l}.005 \\
(.004)\end{array}$ & & $\begin{array}{l}-.001 \\
(.001)\end{array}$ & \\
\hline $\begin{array}{l}\text { Average or individual } \\
\text { conflict reported }\end{array}$ & $\begin{array}{l}-.002 \\
(.189)\end{array}$ & & $\begin{array}{l}.367 \\
(.032)\end{array}$ & \\
\hline $\begin{array}{l}\text { High issue salience (vs. } \\
\text { medium or low salience) }\end{array}$ & & $\begin{array}{l}.711 \\
(.178)\end{array}$ & & $\begin{array}{l}.002 \\
(.095)\end{array}$ \\
\hline $\begin{array}{l}\text { High or "intense" conflict } \\
\text { surrounding issue }\end{array}$ & & $\begin{array}{l}-.173 \\
(.149)\end{array}$ & & $\begin{array}{l}.462 \\
(.061)\end{array}$ \\
\hline $\begin{array}{l}\text { Congressional attention to } \\
\text { issue area in last } 6 \text { mos. }\end{array}$ & $\begin{array}{l}-.003 \\
(.003)\end{array}$ & $\begin{array}{l}-.003 \\
(.003)\end{array}$ & $\begin{array}{l}.001 \\
(.002)\end{array}$ & $\begin{array}{l}.002 \\
(.002)\end{array}$ \\
\hline Government is divided & $\begin{array}{l}.351 \\
(.163)\end{array}$ & $\begin{array}{l}.255 \\
(.151)\end{array}$ & $\begin{array}{l}.053 \\
(.098)\end{array}$ & $\begin{array}{l}.048 \\
(.089)\end{array}$ \\
\hline $\begin{array}{l}\text { Proposal initiated by a } \\
\text { federal agency }\end{array}$ & $\begin{array}{l}.104 \\
(.204)\end{array}$ & $\begin{array}{l}.161 \\
(.181)\end{array}$ & $\begin{array}{l}-.228 \\
(.140)\end{array}$ & $\begin{array}{l}-.277 \\
(.117)\end{array}$ \\
\hline $\begin{array}{l}\text { Ln of organization's annual } \\
\text { budget or revenue }\end{array}$ & & & $\begin{array}{l}.056 \\
(.015)\end{array}$ & $\begin{array}{l}.050 \\
(.016)\end{array}$ \\
\hline Constant & $\begin{array}{l}3.488 \\
(.620)\end{array}$ & $\begin{array}{l}\mathbf{3 . 4 3 5} \\
(.215)\end{array}$ & $\begin{array}{r}\mathbf{- 1 . 7 4 0} \\
(.384)\end{array}$ & $\begin{array}{l}-.720 \\
(.369)\end{array}$ \\
\hline Observations & 77 & 77 & 3177 & 3177 \\
\hline$\alpha$ (dispersion parameter) & .390 & .323 & & \\
\hline ML (Cox-Snell) $\mathrm{R}^{2}$ & .023 & .043 & .030 & .017 \\
\hline Prob. $>\bar{\chi}^{2}$ & .000 & .000 & .000 & .000 \\
\hline
\end{tabular}

Notes: The first two models predict the number of lobbyists who work on the issue using negative binomial regression; the unit of analysis is the policy proposal. The second two models predict whether or not a lobbyist contact Congress regarding the issue; the unit of analysis is the lobbyist-issue. Estimates in bold are significant at $\mathrm{p}<.05$. 
Table 4. The effect of presidential support or opposition on the likelihood that a proposal is adopted

Probability that proposal is adopted (logit)

\begin{tabular}{lccc}
\hline Presidential position & $\mathbf{1 . 6 8 1}$ & $\mathbf{1 . 5 0 8}$ & $\mathbf{1 . 7 0 1}$ \\
$\quad(1,0$, or -1) & $(.592)$ & $(.567)$ & $(.600)$ \\
Number of lobbyists in opposition & -.051 & & -.042 \\
& $(.028)$ & & $(.023)$ \\
Number of lobbyists in support & .010 & -.005 & \\
& $(.016)$ & $(.014)$ & .016 \\
Issue salience & .012 & .015 & $(.021)$ \\
& $(.019)$ & $.021)$ & -.778 \\
Average level of conflict reported & -.675 & -1.008 & $(.705)$ \\
& $(.722)$ & $(.680)$ & -.113 \\
Government is divided & -.135 & -.265 & $(.563)$ \\
& $(.564)$ & $(.545)$ & .631 \\
Proposal initiated by agency & .664 & .632 & $(.673)$ \\
& $(.681)$ & $(.666)$ & -.019 \\
Congressional attention to the issue & -.018 & -.019 & $(.012)$ \\
$\quad$ area over the last 6 months & $(.012)$ & $(.012)$ & 3.663 \\
Constant & 3.276 & 3.940 & $(2.310)$ \\
& $(2.387)$ & $(2.294)$ & 77 \\
\hline Observations & 77 & 77 & .220 \\
ML (Cox-Snell) $\mathrm{R}^{2}$ & .225 & .186 & .008 \\
Prob. $>\chi^{2}$ & .012 & .027 & \\
\hline Estimates & & & \\
\hline
\end{tabular}

Estimates are logit coefficients with standard errors in parentheses. Coefficients in bold are significant at $\mathrm{p}<.05$. 


\section{Endnotes}

${ }^{1}$ Baumgartner et al. (2009) found that the support of "high-level government allies," including the president, was the strongest predictor of policy success for interest group lobbyists working toward the officials' policy goal.

${ }^{2}$ A third rationale for greater lobbying is that of LaPira and Thomas (2017), who show that more experienced lobbyists, especially those who formerly worked in Congress, are hired by clients looking to minimize possible harm from government activity. Their argument relates to the conditions under which groups engage different kinds of lobbyists, and it is not relevant to this study's focus on the relationships between interest group activity and presidential activity nor which actor is a more powerful predictor of policy adoption.

${ }^{3}$ See Salisbury et al. 1987, appendix 2, for more details on the sampling procedure.

${ }^{4}$ For example, "FDA, FTC, and USDA announce a joint initiative in food labeling, including declaration of ingredients, and extended open-date and nutritional labeling in standard food items." A nearly complete list of the proposals can be found in Heinz et al. 1993 (several proposals were part of the data collection but dropped for the book).

${ }^{5}$ Specifically, we used partisan polarization, defined as the distance between the Poole and Rosenthal (1997) estimates of Member ideology of each congress, averaged between the two chambers (correlated with divided government at 0.969) and the location of the median member, also using Poole and Rosenthal (1997) first-dimension estimates (correlated with divided government at 0.989 ).

${ }^{6}$ Including in the model all of the control variables that appear in Table 1 also fails to produce a significant relationship between salience and presidential position-taking.

${ }^{7}$ Clustering errors by the proposal yields greater errors than clustering by the lobbyist or the lobbyist's employer, making proposal-clustered errors the most conservative choice.

${ }^{8}$ Our coding of whether each issue was complex may not be entirely consistent with CanesWrone and de Marchi's (2002) definition of complex issues as those that are regulatory-related rather than social-oriented. We did test both our estimates of whether each issue was regulatory or social in its effects, as well as a simpler coding that energy and agriculture issues were technical, while health and labor issues were social. Neither of these codings confirmed their findings.

9 To test the effects of divided government on presidential success, we interacted the president's position with an indicator for unified government and use this and the constituent terms, along with the control variables (salience, conflict, agency-initiated, and congressional attention) to predict the policy outcome. In this model unified government was not a significant predictor of policy outcome $(0.364$ at $p=.535)$, and neither was the interaction between the president's position and unified government $(-2.248$ at $\mathrm{p}=.101)$, while the president's position was still significant (3.01 at $\mathrm{p}=.009$ ). 